ed with the disease might be found.

The Wellcome Trust will contribute $\$ 30$ million to the project, and has already funded three pilot studies. The SNP Consortium of pharmaceutical companies will contribute the remaining $\$ 15$ million.

The consortium consists of AstraZeneca, Bayer, Bristol-Myers Squibb, Hoffmann-La

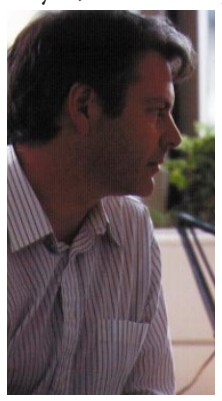

Roche, Glaxo Wellcome, Hoechst Marion Roussel, Novartis, Pfizer, Searle and SmithKline Beecham. The identification and analysis of SNPs will be done at centres involved in the international Human Genome Project.

The US National Institutes of Health has already $\begin{array}{ll}\text { Bentley: maps are } & \text { given } \$ 30 \text { million in grants } \\ \text { 'pre-competitive } & \text { over three years for } a d \text { hoc }\end{array}$ research'? SNP-related projects. The idea that pharmaceutical companies could fund a more comprehensive map emerged from discussions two years ago at the US National Human Genome Research Institute, says Alan Williamson, formerly vice-president for basic research at Merck and a member of the institute's governing council.

Williamson says that pharmaceutical companies were initially approached with the idea of forming a profit-making consortium, which would charge for the use of the map. But those companies that agreed to the idea surprised most observers by insisting that the data should be made available free. The Wellcome Trust's involvement was also conditional on full and free access to the data.

David Bentley, of the Wellcome Trust's Sanger Centre for gene sequencing, says consortium members regard the project as 'precompetitive research', and have agreed not to see any SNP data before they become public.

\title{
Glaxo Wellcome is already using map data
}

[LONDON] The UK-based drugs company Glaxo Wellcome which says that it has patented the idea of a singlenucleotide polymorphism (SNP) map of the human genome (see page 545) has been attempting for some time to incorporate information about variations in gene sequences into its drug discovery programme.

The company became convinced of the feasibility of mapping the variations in nucleotide base pairs in 1997. Within four months, it had used an SNP map from late- onset Alzheimer's patients to narrow down a possible genetic basis for the disease to just two genes - ApoC1 and $A p o E$.

Over the past two years, the company has launched studies of patients with asthma and coronary heart disease, disorders whose genetic basis is less well known. In addition, it asks patients on clinical trials for many of its drugs for permission to include their genetic profiles in a future SNP database.

According to Allen Roses, a vice-president of Glaxo Wellcome and worldwide director of genetics, a more complete SNP map could establish a genetic basis for handling side effects of drugs.

Roses says doctors are reluctant to prescribe an anticonvulsant drug, Lamictal, because five per cent of patients develop a potentially fatal skin rash as a side effect. If a genetic basis for such side effects were found, patients could be screened, and the drug given to the majority not predisposed to developing the rash.
But the consortium's members will receive an additional benefit. By helping to ensure that SNP data are freely available, the larger pharmaceutical companies will not be restricted to the many proprietary SNP databases already being developed by smaller genomics companies. Indeed, these companies are absent from the SNP Consortium, which is made up exclusively of established pharmaceutical companies.

Celera Genomics near Washington DC is compiling a proprietary SNP database in parallel with its efforts to sequence the human genome. Its president, J. Craig Venter, says he welcomes the new SNP consortium.

Venter says he considers it to be more of a "public education programme" in SNPs than a threat to companies such as Celera. He adds that he expects considerable demand for Celera's product, which, he says, is the subject of a possible patent application.

Two pharmaceutical companies outside the consortium - Amgen and Pharmacia UpJohn - have already signed up, says Venter, adding that Celera expects to obtain between 20 and 30 million SNPs within the next 18 months, two orders of magnitude more than the SNP Consortium. Celera's database, he envisages, could also be augmented by data from the SNP Consortium.

But Allen Roses, a vice-president of Glaxo Wellcome and worldwide director of genetics, says 200,000 SNPs are enough for most practical purposes, such as clinical trials.

Roses claims that it is too late to patent an SNP map, as the concept is no longer novel. He says that the basic idea has already been patented by Glaxo Wellcome (see above) following a mapping exercise to find genes associated with Alzheimer's disease.

Furthermore, says Roses, companies marketing SNP databases will not be allowed to sell data obtained from the SNP Consortium back to a consortium member. EhsanMasood

\section{French research would benefit from less paperwork, says report}

[PARIS] France should create a structure to coordinate administrative tasks across its research agencies. This is one of the main conclusions of a report on research bureaucracy, commissioned by the ministry of national education, research and technology and released last week.

The report was prepared by Marc Goujon, a researcher at the Centre National de la Recherche Scientifique (CNRS), and Gérard Chastagnaret, head of the Mediterranean Centre for the Sciences of Man, following extensive consultation in the research community.

Hardly surprisingly, the report confirms that researchers spend increasing amounts of time on administrative tasks, for which they are often poorly qualified. At the same time, the 26,000-strong CNRS, which is often perceived as a bastion of democracy, emerges from the report as relatively efficient.

It dedicates just 8.5 per cent of its staff and 7.6 per cent of its budget to administration - a share that would be the envy of many private companies. In contrast, the computing agency INRIA allocates 35 per cent of its staff and 18 per cent of its budget to management.

The report deplores the way scientists often have to deal with five layers of regulations: Europe, the state, the regions, the agencies to which they belong and the universities where their laboratories are based. It upholds the CNRS's decentralization of administration away from Paris, through the creation of a series of regional delegations, as a model for other agencies to simplify procedures.
The report criticizes the fact that each agency tends to operate in isolation from the others, resulting in incoherence and duplication. Each agency has developed its own expensive solutions to address the Millennium Bug computer problem, for example, and each has its own scientific press. An interagency structure could centralize many tasks such as training and management of laboratory budgets, says the report.

Claude Allègre, the science minister and an Internet enthusiast, is likely to be pleased by one of the report's recommendations: that the paper mountain associated with administering research should be slashed by implementing security systems to give emails the same legal status as signed paper documents.
Declan Butler 